\title{
Haltende nyordning for smertepasienter
}

I dette nummer av Tidsskriftet drøfter Persheim og medarbeidere erfaringer med refusjonsordningen for smertestillende legemidler tre år etter at den ble innført i 2008 (1). Ordningen var resultatet av en lang prosess, og i stortingsmeldingen Rett kurs mot riktigere legemiddelbruk ble det slått fast at smertepasienter hadde vært «en underprioritert pasientgruppe i folketrygdens refusjonsordninger» (2). Dette på tross av at Lønning-utvalget II allerede i 1997 slo fast at disse skulle tilhøre prioriteringsgruppe 1 (3). Den nye ordningen har et begrenset antall billige forhåndsgodkjente smertestillende medisiner som alle leger kan forskrive på blåresept (etter $\S 2$ ). En spesialist må søke Helseøkonomiforvaltningen (HELFO) om refusjon av smertestillende medisiner som er vanedannende, dyre eller som ikke er markedsført i Norge (etter $\S 3 a$ ). Begrunnelsen for dette var bedre kontroll med slik forskrivning og med utgiftene for folketrygden.

Persheim og medarbeidere har analysert nasjonale data over innvilgede søknader fra HELFO i perioden 2008-11, men bare for opioider og pregabalin. De er bekymret over at antallet var raskt økende. Men økningen skyldes vel mest at det tok tid før ordningen ble kjent. Mer fullstendige data fra Reseptregisteret viser at bare $0,14 \%$ av befolkningen fikk utlevert opioidanalgetika på blåresept i 2010 (4). Mer enn 100 ganger så mange har sterke smerter (4).

Forfatterne er bekymret for at det brukes uklare diagnosekoder og koder som ikke er relatert til nevropatiske smerter (i pregabalinsøknader) og for at terapianbefalinger om bruk av opioide analgetika fra Statens legemiddelverk ikke blir fulgt (1). Det som for forfatterne ser ut som en usystematisk bruk av diagnosekoder, skyldes etter vår mening at ICD-10 er ubrukelig for koding av smertetilstander. Den internasjonale smerteorganisasjonen IASP påvirker nå revisjonen av ICD-10 slik at ICD-11 blir mer i tråd med ny kunnskap om smertemekanismer og smertens kliniske fremtredelsesformer. Endringer i nervesystemenes smertekontrollmekanismer påvirker en rekke andre smertetilstander som ikke blir kategorisert som nevropatiske, f.eks. ved artrose og fibromyalgi.

HELFO innvilget mange søknader om kortvirkende opioider for kroniske smerter, og forfatterne påpeker at dette er i strid med terapianbefalinger fra Statens legemiddelverk. Legene støtter seg imidlertid her på mer oppdatert kunnskap: Depottabletter kan øke døgndosen av opioid mer enn når pasienten får ta sin smertemedisin etter behov (5). Bivirkningene er doseavhengige. Det er på tide at Helseog omsorgsdepartementet og Helsedirektoratet gjør noe med de foreldede retningslinjene fra Legemiddelverket. Benzodiazepiner er ikke anbefalt som ledd i farmakologisk behandling av nevropatisk smerte (6). Persheim og medarbeidere har funnet at bare få pasienter fikk innvilget refusjon av benzodiazepiner sammen med opioide analgetika (1). Vi vet ikke hvor mange søknader om benzodiazepiner HELFO avviste. Men reseptregisterdata for 2010 viser at mer enn en tredel av opioidbrukerne får utlevert benzodiazepiner (4). Pregabalin og antidepressiver som har dokumentert effekt på kroniske smerter, har også anxiolytiske virkninger (6). Disse kan brukes når det er nødvendig å dempe angst, uro og depresjoner hos pasienter med ellers terapiresistente smerter medikamentelt (6).

Det er et økende antall pasienter med «helbredet kreft» og plagsomme nevropatiske smerter etter behandlingen. Fem år etter primærbehandling av cancer mammae er det $42 \%$ som har slike smerter (7). En kvinne vi behandlet for en langvarig smertetilstand etter en havarert proteseoperasjon, ble glad da hun fikk kreft og ble kvalifisert til refusjonskode ICPC-90 (palliativ behandling i livets sluttfase): Hun slapp å betale for smertemedisinen. Hun var spesielt glad for å slippe mistenkeliggjøring fra helsepersonell og apotekansatte. Hvem kan si når «livets sluttfase» begynner? Det er et dårlig signal når pasienter gjerne vil at ICPC-90 brukes for å omgå «vanskelig» saksbehandling i HELFO.

I Reseptregisteret er forskrivende leger anonymisert. Til Persheim og medarbeidere har HELFO delt ut ID-nummer på legene som søkte. Med litt bakgrunnskunnskap går det an å identifisere noen av søkerne (1). Vet leger at de slik kan bli gransket av hvem som helst - uten at etikkomiteene kan gripe inn, fordi disse ikke har som mandat å beskytte helsepersonell? Vi vet også at saksbehandlere i HELFO sender bekymringsmeldinger til Fylkeslegen når de synes en lege søker om for store doser av opioid. Det er oppfølgingen av pasienten som avgjør om det er god behandling, ikke opioiddosen $(8,9)$. Persheim og medarbeidere dokumenterer det klinikere vet: At det er stor variasjon mellom de seks HELFO-regionene i innvilging av søknader. Dette kan skyldes ulik kunnskap hos saksbehandlerne eller manglende kunnskap om smertebehandling hos søkerne. Vi er enig med Persheim og medarbeidere i at refusjonsordningen må revideres, men vi - og andre (10) - har ikke samme begrunnelse for dette.

\section{Harald Breivik}

harald.breivik@medisin.uio.no

Audun Stubhaug

Harald Breivik (f. 1940) er professor emeritus ved Universitetet i Oslo og konsulent ved Avdeling for smertebehandling, Akuttklinikken, Oslo universitetssykehus. Han er sjefredaktør i Scandinavian Journal of Pain og tidligere leder i Norsk smerteforening.

Forfatter har fylt ut ICMJE-skjemaet og oppgir ingen interessekonflikter.

Audun Stubhaug (f. 1957) er professor I i anestesiologi ved Universitetet i Oslo og avdelingsleder ved Avdeling for smertebehandling, Akuttklinikken, Oslo universitetssykehus.

Forfatter har fylt ut ICMJE-skjemaet og oppgir ingen interessekonflikter.

\section{Litteratur}

1. Persheim MS, Helland A, Spigset 0 et al. Potensielt vanedannende legemidler på blåresept ved kroniske sterke smerter. Tidsskr Nor Legeforen 2013; 133: $150-4$.

2. St.meld. nr. 18 (2004-2005). Rett kurs mot riktigere legemiddelbruk. www.regjeringen.no/nb/dep/hod/tema/legemidler/legemiddelmeldingen. html?id=226373 (4.1.2013).

3. Norges offentlige utredninger. Prioritering på ny. Gjennomgang av retningslinjer for prioriteringer innen norsk helsetjeneste. NOU 1997: 18. www.regjeringen.no/ nb/dep/hod/dok/nouer/1997/nou-1997-18.html?id=140956 (4.1.2013).

4. Pedersen $L$, Hansen AB, Svendsen $K$ et al. Analgetika med refusjon ved kroniske smerter. Tidsskr Nor Legeforen 2012; 132: 2489-93.

5. Von Korff M, Merrill JO, Rutter CM et al. Time-scheduled vs. pain-contingent opioid dosing in chronic opioid therapy. Pain 2011; 152: 1256-62.

6. Dworkin RH, O'Connor AB, Audette J et al. Recommendations for the pharmacological management of neuropathic pain: an overview and literature update. Mayo Clin Proc 2010; 85 (suppl): S3-14.

7. Peuckmann V, Ekholm O, Rasmussen NK et al. Chronic pain and other sequelae in long-term breast cancer survivors: nationwide survey in Denmark. Eur J Pain 2009; 13: 478-85.

8. Breivik H, Gordh T, Butler S. Keeping an open mind: achieving balance between too liberal and too restrictive prescription of opioids for chronic non-cancer pain: using a two-edged sword. Scand J Pain 2012: 3: 1-4.

9. Watson CP. Chronic non-cancer pain and the long-term efficacy and safety of opioids: some blind men and an elephant? Scand J Pain 2012; 3: 5-13.

10. Jørum E, Warncke T. Behandling av kronisk ikke-malign smerte. Tidsskr Nor Legeforen 2012; 132: 2474. 